\title{
Penerapan Pendekatan Realistic Mathematics Education (Rme) dengan Media Konkret dalam Peningkatan Pembelajaran Bangun Ruang pada Siswa Kelas IV SDN 3 Dorowati Tahun Ajaran 2017/2018
}

\author{
1,2,3 Universitas Sebelas Maret \\ yatiningsih19@gmail.com
}

Yatiningsih ${ }^{1}$, Wahyudi ${ }^{2}$, Ratna Hidayah ${ }^{3}$

\section{Article History}

accepted 01/02/2019

\begin{abstract}
The objective of this research is to describe the improvement of geometry learning through the use of RME approach using concrete media. This research is a collaborative Classroom Action Research (CAR) conducted within three cycles. Each cycle consisted of planning, action, observation, and reflection. The result of this research shows that theuse of RME approach using concrete media can improve the learning of geometry. It was proven by thein crease of learning out comes in the first cycle $83.33 \%$, in the second cycle $89.58 \%$, and in the third cycle $91.67 \%$. The conclusion of this research is the use of RME approach using concrete media can improve the learning of geometry for the fourth-grade students of SDN 3 Dorowati in the academic year of 2017/2018.
\end{abstract}

Keywords: RME, concrete media, geometry

\section{Abstrak}

Tujuan penelitian ini untuk meningkatkan pembelajaran bangun ruang melalui penerapan pendekatan RME dengan media konkret. Penelitian tindakan kelas ini dilaksanakan dalam tiga siklus dan tiap siklus terdiri dari dua pertemuan yang meliputi perencanaan, pelaksanaan, pengamatan, dan refleksi. Hasil penelitian menunjukkan pendekatan Realistic Mathematics Educations (RME) dengan media konkret dapat meningkatkan pembelajaran bangun ruang. Persentase ketuntasan siswa pada siklus I sebesar $83,33 \%$, siklus II 89,58\%, dan siklus III 91,67\%. Simpulan penelitian ini adalah penerapan pendekatan Realistic Mathematics Educations (RME) dengan media konkret dapat meningkatkan pembelajaran bangun ruang pada siswa kelas IV SDN 3 Dorowati tahun ajaran 2017/2018.

Kata Kunci: RME, Media Konkret, Bangun Ruang 


\section{PENDAHULUAN}

Sekolah merupakan tempat atau lembaga dimana siswa dan guru saling berinteraksi dalam proses pembelajaran. Tujuan pembelajaran tercapai dengan baik apabila proses belajar mengajar dilaksanakan secara efektif dan menarik perhatian siswa. Oleh sebab itu, pembelajaran yang menarik harus memfasilitasi siswa untuk mencapai tujuan pembelajaran secara optimal dengan cara menyenangkan sehingga siswa menjadi aktif, kreatif, dan mempunyai motivasi tinggi untuk belajar, termasuk pada pelajaran matematika. Matematika merupakan suatu disiplin ilmu yang dapat meningkatkan kemampuan berpikir siswa, kemampuan berargumentasi, serta memberikan kontribusi dalam pemecahan masalah sehari-hari dan dukungan terhadap pengembangan ilmu pengetahuan dan teknologi (Susanto: 2016, 185). Bangun ruang merupakan salah satu materi yang diajarkan di kelas IV. Menurut Wahyudi (2015: 368) bangun ruang merupakan suatu bangun yang tidak seluruhnya terletak dalam bidang. pembelajaran matematika tentang bangun ruang pada siswa kelas IV SD yaitu suatu proses pembelajaran melalui interaksi antara siswa dengan guru dan lingkungannya yang mengkaji suatu disiplin ilmu matematika tentang bangun ruang.

Berdasarkan hasil wawancara dan observasi pada kelas IV SD, dapat diketahui bahwa pembelajaran masih berpusat pada guru. Guru juga belum menggunakan pendekatan pembelajaran yang berpusat pada siswa. Selain itu, guru belum menggunakan media untuk membantu siswa memahami materi pelajaran. Hasil pratindakan pembelajaran bangun ruang, rerata siswa masih di bawah KKM (70) dengan presentase ketuntasan $20,82 \%$ dengan rerata 36,67 . Hal ini menunjukkan pemahaman siswa tentang bangun ruang masih kurang. Oleh sebab itu, perlu diadakan perbaikan. Salah satunya menggunakan penerapan pendekatan RME dengan media konkret.

Realistic Mathematics Education (RME) merupakan suatu pendekatan yang mengaitkan antara mata pelajaran dengan masalah realistik yang benar-benar dialami manusia melalui proses matematisasi baik secara vertikal maupun horisontal (Wahyudi, 2015: 25). Peneliti juga menggunakan media konkret agar siswa lebih mudah memahami materi dan aktif dalam pembelajaran. Penggunaan media berupa benda-benda konkret dapat memperbaiki proses belajar mengajar, karena siswa belajar langsung dan tidak hanya mendengarkan penjelasan guru maupun mengamati gambar yang disajikan oleh guru (Sanaky, 2013: 129).

Pendekatan $R M E$ dengan media konkret adalah suatu pendekatan yang mengaitkan matematika dengan masalah nyata dan masalah yang dapat dibayangkan peserta didik dalam kehidupan sehari-hari sehingga dapat membantu siswa membangun dan menciptakan kembali konsep matematika yang didukung oleh penggunaan media konkret untuk mencapai tujuan pendidikan matematika yang lebih baik daripada sebelumnya.

Langkah-langkah penerapan pendekatan Realistic Mathematics Education (RME) dengan media konkret meliputi: (1) memahami masalah kontekstual menggunakan media konkret, (2) menjelaskan masalah kontekstual dengan media konkret, (3) menyelesaikan masalah kontekstual dengan media konkret, (4) membandingkan dan mendiskusikan jawaban dengan media konkret, dan (5) menarik kesimpulan dengan media konkret. Melalui penggunaan pendekatan $R M E$ dengan media konkret, akan membuat suasana belajar lebih menyenangkan karena menggunakan masalah riil dan penggunaan media konkret akan membuat siswa lebih tertarik dan aktif untuk mengikuti pembelajaran.

Berdasarkan uraian di atas, dapat diambil rumusan masalah, yaitu: (1) bagaimana penerapan pendekatan $R M E$ dengan media konkret dalam peningkatan pembelajaran bangun ruang pada siswa kelas IV SDN 3 Dorowati tahun ajaran 2017/2018?, (2) apakah penerapan pendekatan RME dengan media konkret dapat 
meningkatkan pembelajaran bangun ruang pada siswa kelas IV SDN 3 Dorowati tahun ajaran 2017/2018?

Tujuan penelitian ini yaitu: (1) mendeskripsikan penerapan pendekatan $R M E$ dengan media konkret dalam peningkatan pembelajaran bangun ruang pada siswa kelas IV SDN 3 Dorowati, dan (2) meningkatkan pembelajaran bangun ruang dengan penerapan pendekatan $R M E$ dengan media konkret pada siswa kelas IV SDN 3 Dorowati tahun ajaran 2017/2018.

\section{METODE}

Penelitian dilaksanakan di SDN 3 Dorowati, Klirong, Kebumen. Subjek penelitian ini adalah siswa kelas IV SDN 3 Dorowati dengan jumlah 24 siswa yang terdiri atas 13 siswa laki-laki dan 11 siswa perempuan. Penelitian ini dilaksakan pada bulan November 2017 sampai Mei 2018.

Penelitian ini menggunakan teknik pengumpulan data yaitu teknik non tes dan teknik tes. Instrumen teknik non tes berupa lembar observasi dan pedoman wawancara. Instrumen teknik tes berupa lembar evaluasi. Untuk menguji validitas data penelti menggunakan triangulasi teknik dan triangulasi sumber. Teknik analisis data pada penelitian ini menggunakan data kuantitatif yang berupa hasil belajar siswa, dan data kualitatif berupa hasil observasi dan wawancara. Menurut Miles dan Huberman (Sugiyono, 2012: 337) ada tiga langkah pengolahan data kualitatif yaitu (1) reduksi data, (2) penyajian data, dan (3) penarikan kesimpulan.

Prosedur penelitian ini menggunakan metode penelitian tindakan kelas kolaboratif. Penelitian tindakan kelas ini menggunakan model yang dikembangkan oleh Kemmis dan Mc Taggart (Arikunto, 2013: 131), yaitu perencanaan, pelaksanaan, observasi, dan refleksi.

\section{HASIL DAN PEMBAHASAN}

Penerapan pendekatan $R M E$ dengan media konkret pada pembelaaran bangun ruang pada siswa kelas IV SDN 3 Dorowati dilaksanakan dalam tiga siklus. Setiap siklus terdiri dari dua pertemuan. Data hasil observasi dari 3 observer penggunaan pendekatan RME dengan media konkret terhadap guru pada siklus I, II, dan III yaitu:

Tabel 1. Perbandingan Penggunaan Pendekatan RME dengan media konkret terhadap guru

\begin{tabular}{lrrc}
\hline & Siklus I & Siklus II & Siklus III \\
\hline Rerata & 3,44 & 3,55 & 3,68 \\
\hline$\%$ & 86,22 & 88,81 & 92,05 \\
\hline
\end{tabular}

Berdasarkan tabel 1, dapat disimpulkan bahwa rerata penggunaan pendekatan RME dengan media konkret mengalami peningkatan, pada siklus I 86,22\%, pada siklus II $88,81 \%$, dan pada siklus III 92,05\%. Siklus II mengalami peningkatan $2,59 \%$ dari siklus I. Siklus III meningkat $3,24 \%$ dari siklus II. Data observasi didukung hasil wawancara terhadap guru dan siswa, dan dapat disimpulkan bahwa kegiatan pembelajaran sudah sesuai skenario pembelajaran dan sudah mencapai indikator kinerja penelitian sebesar $85 \%$. Hasil observasi terhadap siswa terkait penerapan pendekatan RME dengan media konkret pada siklus I, siklus II, dan siklus III dapat dilihat pada tabel 2. 
Tabel 2. Perbandingan Penggunaan Pendekatan RME dengan media konkret pada siswa

\begin{tabular}{lrrc}
\hline & Siklus I & Siklus II & Siklus III \\
\hline Rerata & 3,44 & 3,51 & 3,60 \\
\hline$\%$ & 86,19 & 87,91 & 90,03 \\
\hline
\end{tabular}

Berdasarkan tabel 2, dapat disimpulkan bahwa rerata persentase penerapan pendekatan $R M E$ dengan media konkret pada siswa mengalami peningkatan dari siklus I sebesar $86,19 \%$ menjadi $87,91 \%$ pada siklus II, dan siklus III menjadi $90,03 \%$. Siklus II meningkat sebesar $1,72 \%$ dari siklus I, siklus III meningkat $2,12 \%$ dari siklus II. Persentase penggunaan penerapan pendekatan RME dengan media konkret terlaksana dengan sangat baik. Hasil belajar siswa diukur dengan tes evaluasi dengan KKM 70 dengan presentase ketutasan $85 \%$. Perolehan rerata nilai hasil belajar siswa pada pratindakan, siklus I, siklus II, dan siklus III disajikan dalam tabel 3.

Tabel 3. Hasil Evaluasi tentang Bangun Ruang pada siswa kelas IV

\begin{tabular}{lccc}
\hline \multirow{2}{*}{ Tindakan } & \multirow{2}{*}{ Rerata } & Presentase (\%) \\
\cline { 3 - 4 } & & Tuntas & $\begin{array}{c}\text { Belum } \\
\text { Tuntas }\end{array}$ \\
\hline Pratindakan & 36,67 & 20,83 & 79,17 \\
\hline Siklus I & 82,71 & 83,33 & 16,66 \\
\hline Siklus II & 84,99 & 89,58 & 10,42 \\
\hline Siklus III & 85,20 & 91,67 & 8,33 \\
\hline
\end{tabular}

Berdasarkan data pada tabel 3 , menunjukkan rerata hasil belajar siswa pada pratindakan sebesar 36,67 dengan presentase ketuntasan 20,83\%. Setelah pembelajaran menggunakan pendekatan RME dengan media konkret, rerata hasil belajar siswa pada siklus I menjadi 82,71 dengan persentase ketuntasan $83,33 \%$. Siklus II menjadi 84,99 dengan persentase $89,58 \%$ dan siklus III menjadi 85,20 dengan persentase ketuntasan $91,67 \%$.

Pembelajaran melalui pendekatan RME dengan media konkret dapat membuat suasana belajar lebih menyenangkan karena menggunakan masalah kehidupan nyata siswa. Hal ini sesuai dengan karakteristik $R M E$ yang dijelaskan oleh Grevemeijer (Vello, Ali, \& Ahmad, 2015: 132) bahwa RME memiliki 5 karakteristik yaitu: (1) menggunakan konteks kehidupan nyata, (2) menggunakan model matematika, (3) menggunakan produksi dan konstruksi, (4) menggunakan interaksi, dan (5) menggunakan keterkaitan. Penggunaan media konkret memberikan pengalaman nyata kepada siswa sehingga pembelajarn lebih bermakna. Hal tersebut dikemukakan Asyhar (2011: 55) yang menyatakan kelebihan dari media konkret yaitu dapat memberikan pengalaman nyata kepada siswa sehingga pembelajaran lebih konkret dan retensi waktunya lama.

Selain itu, penggunaan media konkret membantu siswa lebih aktif dengan memanipulasi media. Menurut Arsaythamby dan Zubainur (2014: 310), kelebihan pendekatan $R M E$ yaitu: (1) siswa aktif dalam pembelajaran, (2) pembelajaran lebih bermakna, (3) penggunaan masalah nyata membuat siswa lebih aktif, dan (4) siswa lebih memahami materi dengan memanipulasi media.

Berdasarkan hasil pengamatan terhadap penerapan pendekatan RME dengan media konkret pada siswa kelas IV SDN 3 Dorowati dapat meningkatkan pembelajaranbangun ruang seperti pada data yang telah diuraikan. 


\section{SIMPULAN}

Berdasarkan penerapan pendekatan $R M E$ dengan media konkret dalam peningkatan pembelajaran bangun ruang pada siswa kealas IV SDN 3 Dorowati tahun ajaran 2017/2018 dapat disimpulkan bahwa: (1) langkah-langkah pendekatan $R M E$ dengan media konkret dalam pembelajaran bangun ruang yaitu: (a) memahami masalah kontekstual menggunakan media konkret, (b) menjelaskan masalah kontekstual dengan media konkret, (c) menyelesaikan masalah kontekstual dengan media konkret, (d) membandingkan dan mendiskusikan jawaban dengan media konkret, dan (e) menarik kesimpulan dengan media konkret, (2) penerapan pendekatan $R M E$ dengan media konkret dapat meningkatkan pembelajaran bangun ruang pada siswa kelas IV SDN 3 Dorowati tahun ajaran 2017/2018 dengan peningkatan presentase ketuntasan hasil hasil belajar pada siklus $I=83,33 \%$, siklus $I I=$ $89,58 \%$, dan siklus $\mathrm{III}=91,67 \%$, (3) kendala penerapan pendekatan $R M E$ dengan media konkret yaitu: (1) guru kurang jelas dalam menjelaskan dan membimbing siswa, (2) guru kurang memberikan waktu untuk mencatat dan membacakan hasil diskusi, (3) ada siswa yang masih pasif dan tidak mau mencatat, (4) siswa kesulitan menemukan jawaban, (5) siswa masih gaduh. Solusinya yaitu: (1) guru menjelaskan dan membimbing siswa dengan bahasa yang mudah dipahami, (2) guru memberikan kesempatan pada siswa untuk mencatat dan membacakan hasil diskusi, (3) guru memberikan reward dan meminta siswa untuk mencatat, (4) guru memberikan media tambahan, dan (5) guru menegur siswa.

Peneliti memberikan beberapa saran agar kualitas pembelajarn meningkat yaitu: (1) bagi guru, pendekatan $R M E$ dengan media konkret dapat dijadikan alternatif untuk meningkatkan pembelajaran bangun ruang, (2) bagi siswa, hendaknya lebih aktif dalam mengikuti pembelajaran, (3) bagi sekolah, hendaknya memberikan sarana prasarana yang memadai sehingga memudahkan guru, dan (4) bagi peneliti lain, hendaknya mampu melakukan penelitian yang lebih baik lagi guna mengikuti perkembangan ilmu pengetahuan dan teknologi. 


\section{DAFTAR PUSTAKA}

Educational Approach Affecht Students' Activities In Primary School?. Procedia Social and Behavioral Sciences 159, 309-313. Diperoleh pada 3 Oktober 2017, dari http://www.scienedirect.com/sciene/article/pii/S1877042814065082.

Asyhar, R. (2011). Kreatif Mengembangkan Media Pembelajaran. Jakarta: Gaung Persada Press.

Sanaky, H. (2013). Media Pembelajaran Intekatif-Inovatif. Yogyakarta: Kaukaba Dipantara.

Sugiyono. (2012). Metode Penelitian Pendidikan. Bandung: Alfabeta.

Susanto, A. (2015). Teori Belajar dan Pembelajaran di Sekolah Dasar. Jakarta: Prenada Media Group.

Veloo, A., Ali, R. M., \& Ahmad, H. (2015). Effect of Realistic Mathematics Education Approach Among Pubic Secondary School Students In Riau, Indonesia. Australian Journal of Basic and AppliedScience 9 (28): 131-135. Diperoleh pada 6 Desember 2017, dari www.ajbasweb.com/old/ajbas/2015/.../131-135.pdf.

Wahyudi. (2015). Panduan Pembelajaran Matematika Sekolah Dasar untuk Guru dan Calon Guru SD. Surakarta: UNS Press.

Mckeown, M. G., Beck, I. L., \& Blake, R. G. K. (2009). Rethinking reading comprehension instruction: A comparison of instruction for strategies and content approaches. Reading Research Quarterly, 44, pp. 218-253.

Rismawati, D. (2016). Peningkatan kemampuan membaca pemahaman melalui akomodasi pada anak berkesulitan belajar membaca di kelas III SDN Bangunrejo 2. Widia Ortodidaktika, 5 (6) pp. 532-540.

USAID. (2015). Pembelajaran Literasi di SD/MI di LPTK. Diperoleh dari pdf.usaid.gov/pdf_docs/PA00M3ST.pdf usaid, pada tanggal 25 November 2017. 